\title{
胆道鏡を用いた肝内結石症の治療経験
}

\begin{tabular}{lllllr}
\multicolumn{5}{c}{ 東京大学第 2 外科 } & \\
村田 & 宣夫 & 別府 & 倫兄 & 万代 & 恭嗣 \\
伊関 & 丈治 & 荒井 & 邦佳 & 伊藤 & 徹 \\
笹子三津留 & 渡辺 & 五朗 & 二川 & 俊二 \\
牛山 & 孝樹 & 和田 & 達雄 & &
\end{tabular}

\section{EXPERIENCE OF THE TREATMENT OF INTRAHEPATIC LITHIASIS BY USING THE CHOLEDOCHOSCOPE}

\author{
Nobuo MURATA, Tomoe BEPPU, Yasutsugu BANDAI, Joji IZEKI, \\ Kuniyoshi ARAI, Toru ITO, Mitsuru SASAGO, Goro WATANABE, \\ Shunji FUTAGAWA, Koki USHIYAMA and Tatsuo WADA
}

The 2 nd Department of Surgery, Faculty of Medicine, University of Tokyo

索引用語：肝内結石症, 胆道内視鏡, 超音波穿刺.

はじめに

肝内結石症の治療は今もって困難な点が多い、両葉に わたる肝内結石症で狭窄が多発している症例は最も治療 が難しいが，右葉に限局している肝内結石症む，右葉切 除は侵襲が大きく，良性疾患に対する手術としては必ず しも良い方法とはいえない。

著者らは1978年より肝内結石症に対して, 胆道内視鏡 による截石術を積極的に行ってきた. 諸家の報告のごと く ${ }^{122}$, 総胆管から胆道鏡を挿入し結石の除去を試みた. しかし,この方法には限界があり,さらに超音波映像下 に結石のある拡張肝内胆管を選択的に穿刺し, その瘦孔 から胆道鏡で結石の除去を行う力法を考案し, 治療に難 沾していた 2 症例に施行し成功した.

症例. 1 : 38 歳. 男子.

特発珄門脈压立進症, 肝内結石症のため東大第 2 外科

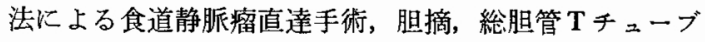
誘導を施行した. $\mathbf{T}$ チューブ抜去後, その癭孔を介して 胆道内視鏡的截石術 (Choledochoscopic lithotomy : 以下 CSL と略す）を施行した. 図1に示すごとく, 有葉後下 区域胆管に狭窄之結石があり, その胆管は左肝管の背側 から左側を回って総胆管に合流する走行異常を認めた. 狭窄部の長さは約 $5 \mathrm{~mm}$ あり, 針子類は角度がうまくと れず結石のある胆管に挿入され難かった。狭窄部の切開
図 1 術後 CSL を試みた際の胆道造影。右後下区 域胆管枝に結石および狭窄が認められる。肝内胆 管の合流異常がある。（症例 1 ）

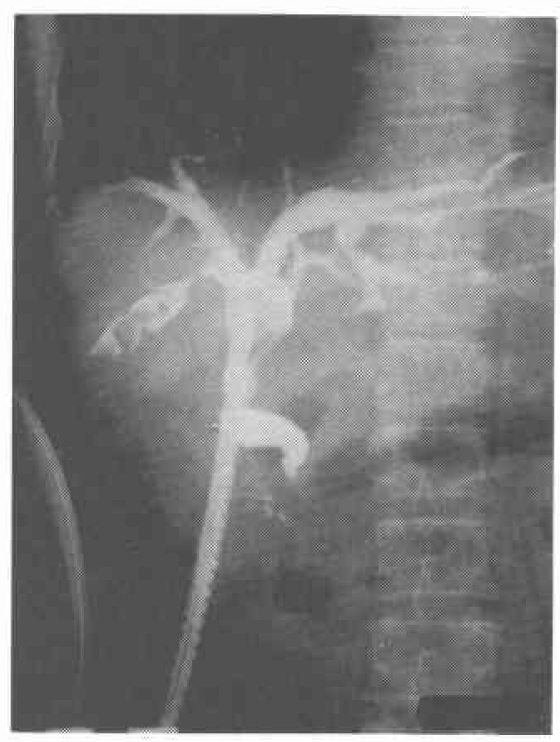

を 3 度試みたが，出血が多く中止した．切開部位を 2 週 間後に観察すると洀痕形成がみられるのみで搪張は不成 功に終った．次に超音波映像下に右側胸部より結石を有 する右葉後下区域胆管を選択的に穿刺し，外径約 $2 \mathrm{~mm}$ 
(1)

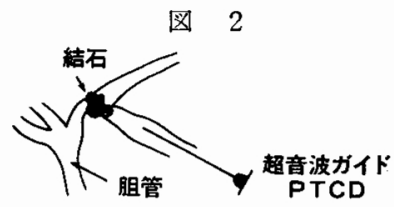

(2)

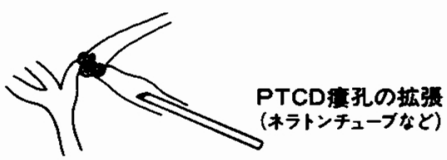

(3)

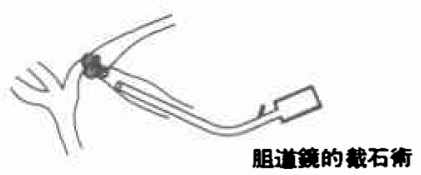

図 3 PTCDチューブからの造影. 右後上区域胆管 に結石が認められる。（症例 2）

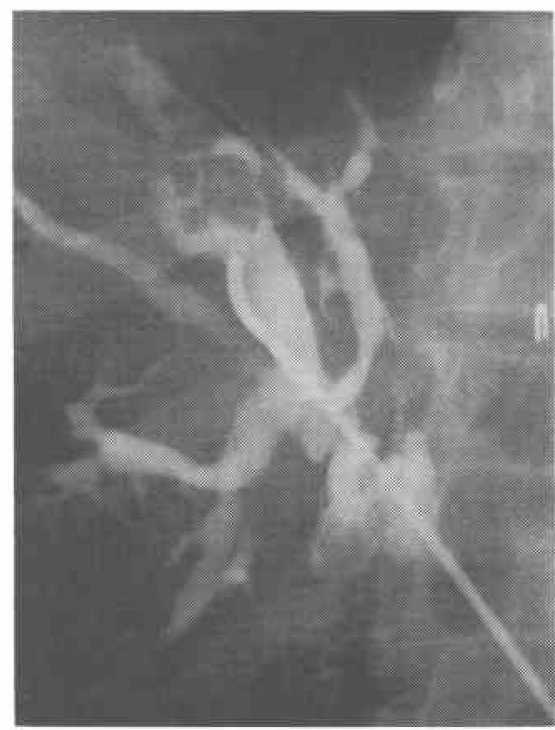

のポリエチレンチューブを挿入した．このチューブを 5 日毎に徐々に太いチュープに交換しつつ瘦孔を拡大し た. 1 カ月後に胆道鏡を插入するに充分な径 $(7 \mathrm{~mm})$ と なり，経皮経肝胆道鏡的截石術を行った（図 2 ).この 際更に分枝にも小結石のあることが判明し，これらも内 視鏡下に完全摘出した。

症例. $2: 28$ 歳. 女子.

黄㾝のために11年前総胆管胃吻合術を受け，1 年前総胆
管拡張症の診断で胆摘, 総胆管切除, 肝管空腸吻合術等 の再手術を受けている. 肝内結石が明らかとなり，教室 にて肝左葉外側区域切除を施行した。術後 9 力月目に39 ${ }^{\circ} \mathrm{C}$ 台の 発熱があり, computed tomography, 超音波検査 にて肝膿癔, 肝内結石症之診断し, 超音波映像下に膿疸 を形成する払張胆管を穿刺，ポリエチンンチューブを挿 入し外瘦とした（図3). 症状が消失した後, 症例 1 と 同様に徐々に太いチューブに交換し膺孔を拡大後, 胆道 鏡にて結石を全て除去し治梥せしめた.

肝内結石症の治療は難しく, 外科的治療上に多くの問 題がある. 近年の本邦に拈ける統計です以前に比べ改善 はしているものの肝内結石症症例に再手術例, 遺残結石 例の多いことが報告されている3(4)51. また治療方針は施 設によって若干異なって扣り 1)46)7/8)，肝内結石症の治 療には難涉しているのが現状である. 最近胆道内視鏡の 開発から，それが肝内結石症の治療に応用されはじめ， 肝内結石症の治療に拈ける胆道鏡的截石術が注目されて ている 2 (8).

著者らは胆撉結石症あるいは総胆管結石症として治療

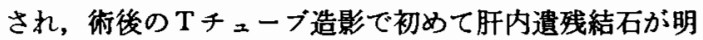
らかになった場合，再手術よりる CSL による非手術的 な結石除去がまず考慮されるべきだと考える．しかし， 肝内結石に対する CSL に関しては消極的な意見もあ

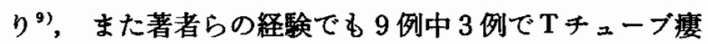
孔からの CSL は成功しておらず (表), CSL で肝内結 石症例すべてを治㾏させうるわけではない，高度狭窄例 や結石のある胆管が鋭角で合流する症例などは, 胆道鏡 あるいは鉬子類を挿入しえないこともありこれらの場 合にはアプローチを変え，超音波誘導 PTCD を行い， その㿔孔から胆道鏡を挿入する経皮経肝胆道鏡による截 石術が極めて有効な治療法となる.

肝内結石症は結石のある胆管の払張を伴って扣り，超 音波装置で結石と扗張胆管を見出し，それを穿刺するの は容易である．著者らは， T千ューブ㾇孔を介しての総 胆管側からの截石が不可能な症例や外胆汁瘦の眉かれて いない症例で超音波映像下に搪張胆管を選択的に穿刺誘 導し, その瘦孔の扗張後に胆道鏡で結石完全除去に成功 した. 経皮経肝胆道鏡はすでに高田ら ${ }^{10)}$, 嶋田ら ${ }^{11 !}$, 二 村ら ${ }^{12}$ が報告しているが，それらは訮内結石症の治療手 段としては行われていないようである.PTCD 㿉孔を拡 張せずに胆管内を生食水で加圧洗浄する方法 ${ }^{13)}$ ，キレー

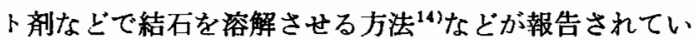




\begin{tabular}{|c|c|c|c|c|c|c|c|c|}
\hline & & & 表 肝 & 内結石 & 䆙例 & & & \\
\hline 箐䁌 & 年各 & 性 & 酧 & 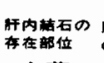 & 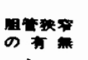 & $\begin{array}{l}\text { CSLO } \\
\text { CStra }\end{array}$ & 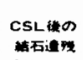 & 于缺 \\
\hline 1 & 36 & $\uparrow$ & $\begin{array}{l}\text { 門脈圧え進症, } \\
\text { 肝内結石症 }\end{array}$ & 右莱 & 有 & 14 & 鰵 & 8 ケ月伐 \\
\hline 2 & 27 & 우 & 肝内結石症 & 両葉 & 有 & 6 & 無 & 9 ヶ月霞 \\
\hline 3 & 30 & 우 & 肝内結石症 & 両菜 & 有 & 4 & 無 & 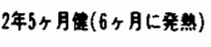 \\
\hline 4 & 63 & $\hat{o}$ & 総䏣管肝内結石症 & 左菜 & 有 & 11 & 篮 & 1年9ヶ月偍 \\
\hline 5 & 60 & $\hat{\sigma}$ & 綵䏣管肝内結石症 & 左菜 & 有 & 2 & 有 & 1年7ヶ月霍 \\
\hline 6 & 40 & 우 & 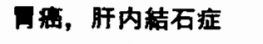 & 右菜 & 有 & 4 & 有 & 1年2ヶ月後に萿死 \\
\hline 7 & 80 & 우 & 総䏣管肝内結石症 & 左菜 & 有 & 4 & 繁 & 7ヶ月偍 \\
\hline 8 & 46 & $\hat{o}$ & 総䏣管肝内結石症 & 左菜 & 有 & 3 & 歓 & 1年4ヶ月健 \\
\hline 9 & 36 & $\hat{\delta}$ & 腿而総䏣管肝内結石症 & 左菜 & 有 & 7 & 無 & 1年7ヶ月健 \\
\hline 10 & 60 & $\hat{\delta}$ & 総䏣管肝内結石症 & 両菜 & 有 & 3 & 無 & 1年6ヶ月健 \\
\hline
\end{tabular}

る. 超音波映像下に選択的に結石のある胆管を穿刺し， ここから例えば溶解剤の注入を行えば，従来のX線透視 下での PTCD 瘦孔から行うより以上の効果が期待され るであろう。しかし, 瘦孔の扗張は慎重に行えば合併症 は少なく，胆道鏡で直視下に截石する利点は大きい。技 術的には，瘦孔の拡大はネラトンチューブあるいは塩化 ビニールなど硬めの材質のものを用いて徐々に太いチュ ーブに交換していくのであるが，この祭ガイドワイヤー またはそれにかわる細くて硬いチューブをスプリントと して太いチューブに換えるのが確実で速い。

選択的経皮経肝胆道外瘦からの CSL の特質として,

(1) 超音波映像下に PTCD の可能な範用なら，どの 肝内胆管枝でも行い得る.

(2) X線透視下の PTC では胆管狭窄の肝蔵側 (proximal）が造影されないこともあり，結石のある胆管を 選択的に穿刺誘導するのは必ずしも容易ではないが，超 音波映像下であれば胆管狭窄の肝臓側に結石がある場合 に，その胆管を選択的に正確に穿刺誘導でさる.

(3) 外胆汁瘦のない場合にでも行い得るために, 繰返 しこの操作が行える.すなわち, 結石完全摘出後に再発 をきたしても，再び同様の手技で結石の除去ができる.

(4) 手術に比して侵襲が遙かに少なく安全確実であ る.

などが挙げられる.

従来より肝内結石症の手術的治療として, 狭窄部分を 含めた肝切除が提唱されているが4)5)83, 結石の所在部位 や患者の状態によっては，このような大きな侵襲の手術 を行えない場合も多い. 肝内結石症が基本的に良性疾患 であることから, 術後胆道鏡を考虑した手術”，結石除 去に主眼を固く侵襲の小さな手術”など比較的安全な治
療法も選択されている. 最近, Fang ${ }^{15)}$ ，日笠ら ${ }^{16)}$ が結石 の再発があった場合に局麻下に結石の摘出ができるよう に，総肝管空腸吻合術兼外腸瘦術を行っている，侵襲を 可能な限り小さくし，再発に備える手術法といえよう. 著者らの選択的経皮経肝胆道鏡による截石術はこのよう な腸瘻は必要とせず，さまざまな状況下で可能な極めて 有用な方法と考学る.

CSL は肝内結石症の治療において，狭窄には手をつ けないという点で根治的治療手段とはいえない。すなわ ち，結石除去を完全に行っても狭窄を残しておれば，胆 汁うっ滿に感染が加わり結石の再発することが充分にあ りらる所である，しかし，結石を完全に除去すれば結石 に起因する感染を抑えるという点で意義は大きい。 た, 結石の再発があっても何度でも著者らの方法で非手 術的に簡単に結石を除去することが可能である．未だ症 例数は少ないが, 安全性, 確実性を備えたこの方法は肝 内結石症の治療に今後大いに役立つと思われる.

著者らが選択的経皮経肝胆道鏡による截石術の適応と 考える症例は以下の如くである.

(1) すでに手術が何回か行われている症例.

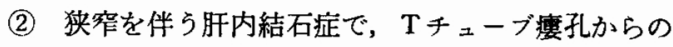
CSL で結石除去の不可能な症例.

(3) 手術的には肝切除でしか結石除去の望めない症例 で risk の高い症例.

等である.

$$
\text { まとめ }
$$

選択的経皮経肝胆道鏡によって治療を行った肝内結石 2 症例を報告した. 肝内結石症の治療は症例に応じた適 切な治療法の選択が必要であるが, 著者らの行ったこの 方法は手術的に外胆汁瘻の造設されていない症例でる可 
能であり，治療に難涉する两葉肝内結石症や総胆管側か らの CSL が成功しない症例, poor risk 症例などで有効 な方法になると思われる。

(本論文の要旨は第22回日本消化器内視鏡学会総会に おいて発表した。)

\section{文献}

1）山川達郎ほ加：肝内結石症に対する内視鏡的了 プローチ. 日臨外会誌, 37：161-169，1976.

2) Gocho, K., et al.: Postoperative choledochofiberscopic removal of intrahepatic stones. Jap. J. Surg., 7: 18-27, 1977.

3) 木下博明: 肝内結石をめぐる諸問題一最近 5 年 間の疫学的統計. 日臨外会誌, $37: 129-132$, 1976.

4) 佐藤寿雄 ほか: 肝内結石症の治療. 外科治療, 20: 530-536, 1978.

5) Nakayama, F., et al.: Hepatolithiasis in Japan. Am. J. Surg., 139: 216-220, 1980.

6) Nagase, M., et al.: Tteatment of intrahepatic gallstones. Arch. Jap. Chir., 47: 467-473, 1978.

7)富田清児ほか：肝内結石症の治療, 手術。23：
$758-766,1969$.

8) 澤田誠之：原発性肝内結石症. 胆と膵， 1 ： $719-727,1980$

9) 福嶋博汪か：遗残結石症, 肝内結石症に対す る術後胆道 Fiberscope による Approach. 日消 外会誌, $13: 850-855,1980$.

10）高田忠敬ほか：経皮的胆道内視鏡検查法に関す る 検討. Gastroenterological Endoscopy, 16 : 106-111, 1974.

11）嶋田紜汪か：胆道内視鏡による術後の遺残結 石, 䀒内結石に対する治療。外科治療, 38 : $325-335,1978$.

12) 二村雄次注か：経皮経肝胆道鏡の研究. Gastroenterological Endoscopy, $22: 134,1980$.

13)福島靖彦活か：肝内結石症治療に対する経皮的 胆管ドレナージの応用。外科診療, 19：7377, 1977.

14）白松幸爾 ほか：遗残結石に対する非鼬血的治 療. 外科治療, 41：238一-242, 1979.

15) Fang, K., et al.: Subcutaneous blind loopA new type of hepaticocholedochojejunostomy for bilateral intrahepatic calculi. Chinese Med. J., 3: 413—418, 1977.

16）日笠頼則ほか：遗残結石一手術療法の実際。臨 床外科, $35: 57-64,1980$. 